\title{
Comperative study of maceration and ultrasonic-assisted extraction of galantamine and lycorine content and antioxidant activity of Galanthus elwesii Hook
}

\author{
Ebru BATI AY ${ }^{i D}$, Muhammed Akif AÇIKGÖZ ${ }^{i{ }^{2}}$, Beril KOCAMAN ${ }^{\text {iD }}$, Şevket Metin KARA 2 \\ 1Suluova Vocational School, Amasya University, Amasya \\ ${ }^{2}$ Faculty of Agriculture, Ordu University, Ordu
}

Alınış tarihi: 17 Ağustos 2020, Kabul tarihi: 6 Kasım 2020

Sorumlu yazar: Ebru BATI AY, e-posta: ziraatciebru@hotmail.com

\begin{abstract}
Galanthus elwesii Hook is a medically and economically important species that contains acetylcholinesterase inhibitory alkaloids galantamine and lycorine with well-known biological activities. In a field experiment, different plant parts of $G$. elwesii were harvested at three growing stages: flowering, post-flowering and fruit set. A comparative evaluation of maceration and ultrasonic-assisted extraction of galantamine and lycorine from these plant parts was implemented. The antioxidant activities and the contents of total phenolic and flavonoid of different plant parts were also investigated. The quantfication of galantamine and lycorine in the extracts was carried out by Reversed-phase High-Performance Liquid Chromatography. The HPLC analysis showed that ultrasonic-assisted extraction displayed higher quantities of galantamine, lycorine, total phenolic compounds and flavonoid and stronger antioxidant activity than maceration extraction. The highest amount of galantamine and lycorine was found in the root and leaf samples taken at fruit set as 89.27 and $23.20 \mu \mathrm{g} \mathrm{g} \mathrm{g}^{-1}$, respectively. Further, the leaf and bulb samples of fruit formation yielded the highest total phenolic and flavonoid contents of 45.58 and $60.92 \mathrm{GAE} \mathrm{g}^{-1}$ DW, respectively. In addition, higher antioxidant activities were observed with the leaf and bulb samples harvested at the stage of fruit set.
\end{abstract}

Key words: Acetyl cholin esterase, Amaryllidaceae, Antioxidant activity, Snowdrop

\begin{abstract}
Ultrasonik destekli ve maceration ile ekstrakte edilen Galanthus Elwesii Hook'un antioksidan kapasitesilerinin, galantamin ve lycorine miktarlarının karşılaştırılması
\end{abstract}

Öz

Galanthus elwesii Hook acetylcholinesterase inhibitörü galantamin ve antikanser aktivite gösteren lycorine alkaloitlerini tüm bitki kısımlarında içeren tıbbi ve ekonomik açıdan önemli bir türdür. Bu tarla denemesinde $G$. elwesii'nin farklı bitki kısımları üç farklı gelişme döneminde (çiçeklenme, çiçeklenme sonrası ve meyve tutumu) hasat edilerek ultrasonik destekli ve maserasyon yöntemleri ile ekstrakte edilmiştir. Bitki örneklerinin antioksidan aktiviteleri ile galantamin, likorin, toplam fenolik ve flavonoid içerikleri bu iki yönteme göre karşılaştırılmıştır. Galantamin ve likorin miktarları Ters Faz-Yüksek Performanslı Sıvı Kromatografisi ile belirlenmiștir. Ultrasonik destekli ekstraksiyon yönteminde antioksidan aktivite, alkaloid, toplam fenolik ve flavonoid içeriği açısından daha yüksek ve daha etkili sonuçlar elde edilmiştir. Galantamin ve likorin meyve bağlama döneminde sırasıyla 89.27 ve $23.20 \mu \mathrm{g}$ g-1 olarak kök ve yaprak örneklerinde en yüksek değere ulaşmıștır. Ayrıca en yüksek toplam fenolik ve flavonoid miktarları da (sirasıyla 45.58 ve 60.92 GAE g-1 $^{-1}$ DW) aynı dönemdeki yaprak ve soğan örneklerinde elde edilmiștir. Bunun yanı sıra meyve bağlama döneminde hasat edilen yaprak ve soğan örneklerinin antioksidan kapasitelerinin daha yüksek olduğu gözlenmiștir.

Anahtar kelimeler: Acetylcholinesterase, Amaryllidaceae, Antioksidan aktivite, Kardelen

Batı Ay, E., Açıkgöz, M.A., Kocaman, B., \& Kara, S.M. (2020). Comperative study of maceration and ultrasonic-assisted extraction of galantamine and lycorine content and antioxidant activity of Galanthus elwesii Hook. Akademik Ziraat Dergisi, 9(2), 297-306. 


\section{Introduction}

Amaryllidaceae is an extremely important family that contains many economically and medically valuable bulbous species, represented by about 1600 species and 85 genera worldwide (Christenhusz and Byng, 2016). The family, which is spread in warm regions, subtropical and tropical, is also one of the most important basis of valuable alkaloids with a wide range of biological activities as well as being known with its beautiful and fragrant flowers all over the world (Nair et al., 2013; Nair and van Staden, 2013; Nair and van Staden, 2014). Galantamine and lycorine are the most important of the phenylalanine and tyrosine-derived alkaloids produced only in the flowers and bulbs of snowdrops, daffodils and spider lilies belonging to the Amaryllidaceae. Galantamine is widely used in Alzheimer's disease in the European Union and the United States (Houghton, 2006), while lycorine is known to have anticancer, anti-inflammatory, antifungal, antidepressant, antinociceptive and cholinesterase-inhibiting biological activities (Nair and van Staden, 2013; Van Goietsenoven et al., 2013; He et al., 2015; Cimmino et al., 2017). Growth and development periods, harvest time (Ay et al., 2018), climate, soil structure and cultural practices (Khonakdari et al., 2018) have a significant role in enhanced synthesis of these alkaloids in plants. There are different techniques (conventional and non-conventional) used to extract bioactive compounds from plants (Azmir et al., 2013; Petruczynik et al., 2016). Among these techniques, ultrasonic-assisted extraction comes to the fore due to less time and energy consumption and higher extraction efficiency (Chemat et al., 2017). High power density and sound wave frequency in ultrasonic-assisted extraction cause cavitation on the surfaces of plant samples (Vinatoru, 2001; Chemat and Khan, 2011). This is followed by the cavitation bubbles' burst that causes the cell wall to break down, increasing the release of bioactive compounds (Chemat and Khan, 2011; Chemat et al., 2017). It can also be said that this method is environmentally friendly, as less solvent is used compared to the conventional extraction methods (Chemat and Khan, 2011; Chemat et al., 2017).

Studies of many species have revealed that many alkaloids -fangchinoline and tetrandrine (Zhang et al., 2009), vinblastine, vindoline and catharanthine (Yang et al., 2011), berberine, palmatine and jatrorrhizine (Wang et al., 2015), galantamine and lycorine (Petruczynik et al., 2016) are obtained more efficiently and at a high rate by ultrasonic-assisted extraction than conventional extraction methods. However, to date, the effectiveness of this method in Galanthus elwesii Hook's plant specimens has not been compared with maceration, one of the traditional extraction methods. Additionally, the variation of galantamine and lycorine quantities in distinct parts of the plant (flower, leaf, bulb and root) during the flowering, post-flowering and fruit ripening stages have not been previously investigated. With this research, the effectiveness of ultrasonic-assisted and maceration extraction methods waere compared in Galanthus elwesii. Furthermore, antioxidant capacities, galantamine and lycorine quantities of plant parts harvested during different development periods were determined.

\section{Material and Methods}

\section{Plant Material And Field Site Description}

Galanthus elwesii bulbs (4 g each) were obtained from Floramarla Ornamental Plants Company, Yalova, Turkey. In the last week of September 2016, the bulbs were planted in the experimental field to a depth of 4-6 cm, in Amasya (latitude $40^{\circ} 81^{\prime} \mathrm{n}$, longitude $35^{\circ} 73^{\prime}$ e, altitude, $510 \mathrm{~m}$ above sea level) in central Anatolia, Turkey. The weather in this area is hot in summers and relatively cold in winters. The average rainfall in the first six months of 2017 was $248.8 \mathrm{~mm}$ with an average temperature of $14.4^{\circ} \mathrm{C}$ and relative humidity of $58.5 \%$ (Amasya Regional Directorate of Meteorology, 2017). The main characteristics of the soil are as follows: loamy structure, $\mathrm{pH} 7.99$, EC $0.49 \mathrm{ds} / \mathrm{m}$, organic matter $1.2 \%$, potassium-rich $\left(47 \mathrm{~kg} \mathrm{da}^{-1}\right)$ and $17.2 \%$ lime. Prior to planting, basic fertilization was practiced in the ratios of $50 \mathrm{~kg} / \mathrm{ha} \mathrm{N}$ and $50 \mathrm{~kg} / \mathrm{ha}_{2} \mathrm{O}_{5}$. The weed control was carried out by hand and no irrigation was performed during the study. Galanthus elwesii bulbs were planted using $0.25 \times 0.5$ $\mathrm{m}$ intra- and interrow spaces in plots with ten $8 \mathrm{~m}$ long rows. Different parts of the plants (flowers, leaves, bulbs, and roots) were harvested separately at distinct growing stages including flowering, postflowering, and fruit set. During the flowering stage (03.02.2017) the flower, leaf, bulb and root parts were harvested, while after flowering (28.02.2017) and during fruit set (18.03.2017) only the leaf, bulb and root parts were harvested. Within each plot, 20 plants were randomly chosen and totaly 60 plants (with 3 replicates) were harvested in the study for 
each plant sample. In order to avoid stress factors as a result of injury in plants, underground and aerial parts of the plants were taken completely. After harvest, the plant samples were dried in shade at room temperature for 17-21 days.

\section{Extraction methods}

\section{Ultrasonic-assisted extraction (UAE)}

The extraction process of $G$. elwesii test piece was performed using ultrasonic bath (ULT AG 440, Germany) planned with $35 \mathrm{kHz}$ fixed frequency and power density $(180 \mathrm{~W})$. Powder plant samples were weighed to be $5 \mathrm{~g}$ each and mixed with $200 \mathrm{ml}$ methanol. The resulting mixture was then kept at 45 ${ }^{\circ} \mathrm{C}$ for $72 \mathrm{~h}$. The extracts were filtered with the help of Whatman No. 1 filter paper and dried under vacuum at $40{ }^{\circ} \mathrm{C}$ using a rotary evaporator (Buchi Rotavapor R-114, Switzerland). The dried extracts were refrigerated at $+4{ }^{\circ} \mathrm{C}$ until necessary analysis.

\section{Maceration extraction (ME)}

Conventional/maceration extraction process was performed according to Vongsak et al. (2013) except for some modifications. Powder plant samples were weighed $5 \mathrm{~g}$ each, and $200 \mathrm{ml}$ methanol was added. The final solution was then shaken with the help of a rotary shaker at $30{ }^{\circ} \mathrm{C}$ for $72 \mathrm{~h}$. The extracts were filtered using Whatman No. 1 filter paper and vacuum dried at $40{ }^{\circ} \mathrm{C}$ with a rotary evaporator (Buchi Rotavapor R-114, Switzerland). The dried extracts were refrigerated at $+4{ }^{\circ} \mathrm{C}$ until necessary analysis.

\section{Galantamine and lycorine content}

Galantamine and lycorine contents of the extracts were specified by RP-HPLC analysis that was conducted using the Shimadzu Prominence Modular LC20A system (C18 column; 250 x $4.6 \mathrm{~mm}$ id, $5 \mu$ ). The column was controlled at $280{ }^{\circ} \mathrm{C}$ and the injection was arranged to $20 \mu \mathrm{l}$. The solution was designed by changing the proportion of solvent $B$ (acetonitrile) to solvent A (acetic acid). The solvent B proportion in the solution was shifted from $10 \%$ to $40 \%$ progressively during the first $28 \mathrm{~min}$, from $40 \%$ to $60 \%$ up to $39 \mathrm{~min}$, and from $60 \%$ to $90 \%$ up to $50 \mathrm{~min}$. The mobile phase composition was shifted compared to the first condition in 55 min and kept for $10 \mathrm{~min}$, the same application was done for the other samples. Chromatograms were monitored at 272 and $310 \mathrm{~nm}$ (Seal, 2016). All compounds were determined separately by comparing with the related standards and calibration curves.

\section{Measurement of total phenolic and flavonoid compounds}

The total phenolic contents of the plant extracts were determined using the Folin-Ciocalteu reagent method as described by Wolfe et al. (2003). Absorbance was measured at $760 \mathrm{~nm}$, standard curve (5-1000 mg, $0.1 \mathrm{ml}^{-1}$ ) was obtained with the standard gallic acid solution, and the results were expressed in gallic acid equivalent $\mathrm{mg} \mathrm{g}^{-1}$. The total flavonoid compounds of the plant extracts were measured with the method reported in the literature and using aluminum chloride $\left(\mathrm{AlCl}_{3}\right)$ and quercetin as standards (Fazal et al., 2016). The results were expressed as quercetin (mg QE $\mathrm{g}^{-1}$ ) after obtaining the standard curve.

\section{Antioxidant activity \\ DPPH free radical scavenging activity}

Free radical-scavenging capacity was tested by the DPPH assay with the procedure of Brand-Williams et al. (1995). Briefly, different concentrations $(25,50$, 100 and $200 \mu \mathrm{g} \mathrm{ml}^{-1}$ ) of the extracts were prepared. DPPH solution and the extracts were mixed $(1.5 \mathrm{ml}$ of $20 \mathrm{mg} \mathrm{ml}^{-1} \mathrm{DPPH}$ solution and $0.75 \mathrm{ml}$ from each of the extracts) in methanol. The resulting solution was put into butylated hydroxyanisole (BHA). The mixture was then vortexed and kept at dark condition. The absorbance values of the reaction mixtures were measured at $517 \mathrm{~nm}$ using UV-vis spectrophotometer. The radical-scavenging activities of the samples, expressed as percentage scavenging capacity of DPPH, were calculated according to the formula below: \% scavenging capacity $=(\mathrm{CA}-\mathrm{SA}) / \mathrm{CA}$ $x 100$, where SA is the sample absorbance and CA is the control absorbance.

\section{Reducing power assay (RPA)}

The reductive potential was measured with the method reported in the literature (Oyaizu, 196). Different concentrations $\left(25,50,100\right.$ and $200 \mu \mathrm{g} \mathrm{ml}^{-}$ 1 ) of the extracts were mixed with phosphate buffer $(2.5 \mathrm{ml}, 0.2 \mathrm{M})$ and potassium ferricyanide [2.5 $\mathrm{ml}$, $\left.1 \% \mathrm{~K}_{3} \mathrm{Fe}(\mathrm{CN})_{6}\right]$. The $\mathrm{pH}$ of the phosphate buffer was set to 6.6. The extracts were retained at $50{ }^{\circ} \mathrm{C}$ for 30 min. Afterwards, $2.5 \mathrm{ml}$ of trichloroacetic acid (10\%, $\mathrm{w} \mathrm{v}^{-1}$ ) was added to the mixture and centrifuged at $3000 \mathrm{rpm}$ for $10 \mathrm{~min}$. Finally, $2.5 \mathrm{ml}$ of upper-layer solution was mixed with $2.5 \mathrm{ml}$ distilled water and $0.5 \mathrm{ml} \mathrm{FeCl}_{3}\left(0.1 \%, \mathrm{w} \mathrm{v}^{-1}\right)$, and the absorbance was measured at $700 \mathrm{~nm}$ in a spectrophotometer. 


\section{Metal chelating activity (MCA)}

The chelating activities of extracts were analyzed on ferrous ions $\left(\mathrm{Fe}_{2}+\right)$ as described by Decker and Welch (1990). One $\mathrm{ml}$ from distinct concentrations $(25,50$, 100 and $200 \mu \mathrm{g} \mathrm{ml}^{-1}$ ) of the extracts and $3.7 \mathrm{ml}$ of distilled water were mixed. The mixed solutions were held in $0.1 \mathrm{ml} \mathrm{FeCl} 2(2 \mathrm{mM})$ for $30 \mathrm{~min}$. When 5 $\mathrm{mM}$ and $0.2 \mathrm{ml}$ ferrozine added to the solution, the reaction proceeded for ten min. The absorbances of the solutions were measured at $562 \mathrm{~nm}$. EDTA and the chelating activity were compared. MCA was calculated according to the formula: Metal chelating activity $(\%)=(C A-S A) / C A \times 100$, where SA is the sample absorbance and $\mathrm{CA}$ is the control absorbance.

\section{Statistical analysis}

Validity and homogeneity of the variance analysis were checked by Kolmogorov-Smirnov test and Levene test, respectively. The comparison of means was performed using the least significant difference (LSD) test at a confidence level of 95\%. Pearson's correlation coefficients between the bioactive compounds and antioxidant capacities were calculated using the SPSS software (SPSS Inc. Chicago IL.V. 22.0). All the tests were performed in triplicates, and the results were presented as mean \pm SD.

Table 1. Galantamine and lycorine contents $\left(\mu \mathrm{g} \mathrm{g}^{-1}\right)$ of the extracts obtained by the ultrasonic-assisted and maceration methods according to the phenological stages and plant parts.

\begin{tabular}{|c|c|c|c|c|c|c|c|c|}
\hline & \multicolumn{8}{|c|}{ Galantamine $\left(\mu \mathrm{g} \mathrm{g}^{-1}\right)$} \\
\hline & \multicolumn{4}{|c|}{ Ultrasonic assisted } & \multicolumn{4}{|c|}{ Maceration } \\
\hline & \multicolumn{4}{|c|}{ Plant parts } & \multicolumn{4}{|c|}{ Plant parts } \\
\hline Phenological stages & Leaf & Flower & Bulb & Root & Leaf & Flower & Bulb & Root \\
\hline Flowering & $\begin{array}{c}0.43 \pm \\
0.01^{\mathrm{c}}\end{array}$ & $\begin{array}{c}0.08 \pm \\
0.00\end{array}$ & $\begin{array}{c}7.09 \pm \\
0.57^{\mathrm{c}}\end{array}$ & $\begin{array}{c}0.18 \pm \\
0.19 c\end{array}$ & nd & $\mathrm{Nd}$ & $\begin{array}{c}4.30 \pm \\
0.54^{\mathrm{b}}\end{array}$ & $\mathrm{Nd}$ \\
\hline Post-flowering & $\begin{array}{c}21.50 \pm \\
1.13^{\mathrm{a}}\end{array}$ & & $\begin{array}{c}32.53 \pm \\
1.54^{\mathrm{a}}\end{array}$ & $\begin{array}{c}0.91 \pm \\
0.08^{\mathrm{b}}\end{array}$ & $\begin{array}{c}19.49 \pm \\
2.30^{\mathrm{a}}\end{array}$ & & $\begin{array}{c}27.52 \pm \\
1.22^{\mathrm{a}}\end{array}$ & $\mathrm{Nd}$ \\
\hline \multirow[t]{4}{*}{ Fruit set } & $\begin{array}{c}8.28 \pm \\
0.42^{\mathrm{b}}\end{array}$ & & $\begin{array}{c}7.74 \pm \\
0.80^{\mathrm{b}}\end{array}$ & $\begin{array}{c}89.27 \pm \\
2.78^{\mathrm{a}}\end{array}$ & $\begin{array}{c}8.28 \pm \\
1.02^{\mathrm{b}}\end{array}$ & & $\begin{array}{c}4.28 \pm \\
0.75^{b}\end{array}$ & $\begin{array}{c}66.80 \pm \\
1.18\end{array}$ \\
\hline & \multicolumn{8}{|c|}{ Lycorine $\left(\mu \mathrm{g} \mathrm{g}^{-1}\right)$} \\
\hline & \multicolumn{4}{|c|}{ Ultrasonic assisted } & \multicolumn{4}{|c|}{ Maceration } \\
\hline & \multicolumn{4}{|c|}{ Plant parts } & \multicolumn{4}{|c|}{ Plant parts } \\
\hline Phenological stages & Leaf & Flower & Bulb & Root & Leaf & Flower & Bulb & Root \\
\hline Flowering & $\begin{array}{c}3.78 \pm \\
0.00^{c}\end{array}$ & $\begin{array}{c}4.35 \pm \\
0.08\end{array}$ & $\begin{aligned} 5.53 \pm \\
0.18^{\mathrm{c}}\end{aligned}$ & $\begin{array}{c}0.45 \pm \\
0.05^{\mathrm{c}}\end{array}$ & $\begin{array}{r}3.51 \pm \\
0.00^{c}\end{array}$ & $\begin{array}{c}3.88 \pm \\
0.30\end{array}$ & $\begin{array}{c}1.53 \pm \\
0.00^{c}\end{array}$ & $\mathrm{Nd}$ \\
\hline Post-flowering & $\begin{array}{c}16.26 \pm \\
0.56^{\mathrm{b}}\end{array}$ & & $\begin{array}{c}6.12 \pm \\
0.15^{b}\end{array}$ & $\begin{array}{c}4.56 \pm \\
0.08^{\mathrm{a}}\end{array}$ & $\begin{array}{c}13.26 \pm \\
0.64^{\mathrm{b}}\end{array}$ & & $\begin{array}{c}3.05 \pm \\
0.05^{\mathrm{a}}\end{array}$ & $\begin{array}{c}3.38 \pm \\
0.08^{\mathrm{a}}\end{array}$ \\
\hline Fruit set & $\begin{array}{c}23.20 \pm \\
1.10^{\mathrm{a}}\end{array}$ & & $\begin{array}{c}9.05 \pm \\
0.40^{\mathrm{a}}\end{array}$ & $\begin{array}{c}3.42 \pm \\
0.22^{\mathrm{b}}\end{array}$ & $\begin{array}{c}21.32 \pm \\
1.58^{\mathrm{a}}\end{array}$ & & $\begin{array}{c}2.33 \pm \\
0.35^{\mathrm{b}}\end{array}$ & $\begin{array}{c}1.92 \pm \\
0.42^{\mathrm{b}}\end{array}$ \\
\hline
\end{tabular}

${ }^{[a]}$ nd: not detected; [b] The result are expressed as means \pm SD $(n=3)$; [c] Means with the same letters are not significantly different at $\% 5$ level.

To date, many researchers have studied lycorine and galantamine which are well-known Amaryllidaceae alkaloids for their anti-tumor, anticancer, antimalarial and AChE inhibitory activities (Cortes et al., 2019; da Costa et al., 2019; Tarakemeh et al., 2019).

\section{Results and Discussion}

\section{Galantamine and lycorine content}

Galantamine and lycorine quantities of G. elwesii samples are presented in Table 1. Galantamine and lycorine quantities were higher in UAE method compared to the maceration method. Galantamine contents of the leaf, flower, bulb and root samples during flowering period were $0.43,0.08,7.09$, and $0.18 \mu \mathrm{g} \mathrm{g} \mathrm{g}^{-1}$, respectively, in UAE. However, in extraction with maceration, only galantamine $(4.30$ $\mu \mathrm{g} \mathrm{g}^{-1}$ ) was detected in the bulb samples harvested at the same period, which is $2.79 \mu \mathrm{g} \mathrm{g}^{-1}$ lower than UAE. The highest amount of galantamine in the UAE was detected in the root samples harvested during fruit formation period as $89.27 \mu^{g^{-1}}{ }^{-1}$. In ME, this amount is approximately $25.2 \%$ lower $\left(66.80 \mu \mathrm{g} \mathrm{g}^{-1}\right)$ than that of UAE. It was determined that the period in which the amount of galantamine in the leaf and bulb samples was the highest was post-flowering period and followed by fruit set $\left(8.28\right.$ and $7.74 \mu \mathrm{g} \mathrm{g} \mathrm{g}^{-1}$, respectively). In the root samples, the highest galantamine accumulation was realized as $89.27 \mu \mathrm{g}$ $\mathrm{g}^{-1}$ during fruit set period. This was followed by postflowering $\left(0.091 \mu \mathrm{g} \mathrm{g}^{-1}\right)$ and flowering $\left(0.018 \mu \mathrm{g} \mathrm{g}^{-1}\right)$, respectively. 
(Emir and Önür, 2016). For example, galantamine has been reported to be present mostly in the leaves of $L$. aestivum, the root of $G$. nivalis and $L$. vernum, while lycorine has been reported to be present mostly in the root of $G$. nivalis and L. aestivum, the leaf of L. vernum (Petruczynik et al., 2016), and the bulbs (compared to aerial parts) of $G$. reginae-olgae subsp vernalis (Conforti et al., 2010). Galantamine and lycorine accumulation in $G$. elwesii has been reported to be more in the aerial parts in some locations, yet in bulbs in some others (Emir et al., 2017). Similar to previous researches, the results of this research show that galantamine and lycorine accumulation vary depending on the phenological periods and plant parts. Furthermore, our results supporting the findings of Petruczynik et al. (2016) revealed that the UAE technique was more effective in the removal of galantamine and lycorine than the maceration method.

Table 2. Total phenolic and flavonoid contents of the extracts obtained by the ultrasonic-assisted and maceration methods according to the phenological stages and plant parts.

\begin{tabular}{|c|c|c|c|c|c|c|c|c|}
\hline \multirow[b]{4}{*}{$\begin{array}{c}\text { Phenological } \\
\text { stages } \\
\end{array}$} & \multicolumn{8}{|c|}{ Total phenolic content (mg GAE g-1 DW) } \\
\hline & \multicolumn{4}{|c|}{ Ultrasonic assisted } & \multicolumn{4}{|c|}{ Maceration } \\
\hline & \multicolumn{4}{|c|}{ Plant parts } & \multicolumn{4}{|c|}{ Plant parts } \\
\hline & Leaf & Flower & Bulb & Root & Leaf & Flower & Bulb & Root \\
\hline Flowering & $\begin{array}{c}28.76 \pm \\
1.08 \mathrm{c}\end{array}$ & $\begin{array}{c}24.35 \pm \\
0.80\end{array}$ & $\begin{array}{c}31.40 \pm \\
0.66^{c}\end{array}$ & $\begin{array}{c}25.62 \pm \\
0.47^{\mathrm{a}}\end{array}$ & $\begin{array}{c}25.32 \pm \\
0.52^{c}\end{array}$ & $\begin{array}{c}20.36 \pm \\
0.85\end{array}$ & $\begin{array}{c}29.88 \pm \\
0.19 \mathrm{c}\end{array}$ & $\begin{array}{c}23.60 \pm \\
0.36^{\mathrm{a}}\end{array}$ \\
\hline $\begin{array}{l}\text { Post- } \\
\text { flowering }\end{array}$ & $\begin{array}{c}33.15 \pm \\
3.20^{\mathrm{b}}\end{array}$ & & $\begin{array}{c}36.43 \pm \\
1.02^{\mathrm{b}}\end{array}$ & $\begin{array}{c}23.20 \pm \\
1.09^{\mathrm{b}}\end{array}$ & $\begin{array}{c}31.56 \pm \\
1.66^{\mathrm{b}}\end{array}$ & & $\begin{array}{c}35.74 \pm \\
1.00^{\mathrm{b}}\end{array}$ & $\begin{array}{c}22.08 \pm \\
0.48^{\mathrm{b}}\end{array}$ \\
\hline \multirow[t]{4}{*}{ Fruit set } & $\begin{array}{c}45.58 \pm \\
1.72^{\mathrm{a}} \\
\end{array}$ & & $\begin{array}{c}45.13 \pm \\
3.35^{\mathrm{a}}\end{array}$ & $\begin{array}{c}19.78 \pm \\
0.77 \mathrm{c} \\
\end{array}$ & $\begin{array}{c}43.81 \pm \\
2.44^{\mathrm{a}} \\
\end{array}$ & & $\begin{array}{c}41.66 \pm \\
3.51^{\mathrm{a}}\end{array}$ & $\begin{array}{c}17.65 \pm \\
0.11^{\mathrm{c}} \\
\end{array}$ \\
\hline & \multicolumn{8}{|c|}{ Total flavonoid content (mg QE g-1 DW) } \\
\hline & \multicolumn{4}{|c|}{ Ultrasonic assisted } & \multicolumn{4}{|c|}{ Maceration } \\
\hline & \multicolumn{4}{|c|}{ Plant parts } & \multicolumn{4}{|c|}{ Plant parts } \\
\hline $\begin{array}{c}\text { Phenological } \\
\text { stages } \\
\end{array}$ & Leaf & Flower & Bulb & Root & Leaf & Flower & Bulb & Root \\
\hline Flowering & $\begin{array}{c}35.42 \pm \\
1.78^{c}\end{array}$ & $\begin{array}{c}33.14 \pm \\
0.58\end{array}$ & $\begin{array}{c}32.10 \pm \\
2.07^{\mathrm{c}}\end{array}$ & $\begin{array}{c}25.64 \pm \\
0.32^{\mathrm{a}}\end{array}$ & $\begin{array}{c}30.18 \pm \\
0.15^{c}\end{array}$ & $\begin{array}{c}29.03 \pm \\
0.48\end{array}$ & $\begin{array}{c}29.81 \pm \\
1.52^{c}\end{array}$ & $\begin{array}{c}25.33 \pm \\
0.94^{\mathrm{a}}\end{array}$ \\
\hline $\begin{array}{c}\text { Post- } \\
\text { flowering }\end{array}$ & $\begin{array}{c}38.12 \pm \\
1.42^{\mathrm{b}}\end{array}$ & & $\begin{array}{c}38.52 \pm \\
0.96^{b}\end{array}$ & $\begin{array}{c}24.05 \pm \\
0.05^{b}\end{array}$ & $\begin{array}{c}35.18 \pm \\
0.73^{\mathrm{b}}\end{array}$ & & $\begin{array}{c}38.42 \pm \\
0.18^{\mathrm{b}}\end{array}$ & $\begin{array}{c}22.76 \pm \\
0.82^{b}\end{array}$ \\
\hline Fruit set & $\begin{array}{c}46.58 \pm \\
0.73^{\mathrm{a}} \\
\end{array}$ & & $\begin{array}{c}60.92 \pm \\
1.00^{\mathrm{a}} \\
\end{array}$ & $\begin{array}{c}22.72 \pm \\
0.57 \mathrm{c}\end{array}$ & $\begin{array}{c}40.63 \pm \\
0.80^{\mathrm{a}} \\
\end{array}$ & & $\begin{array}{c}53.08 \pm \\
2.61^{\mathrm{a}} \\
\end{array}$ & $\begin{array}{c}20.75 \pm \\
0.27 \mathrm{c} \\
\end{array}$ \\
\hline
\end{tabular}

[a] The result are expressed as means \pm SD $(n=3)$; [b] Means with the same letters are not significantly different at $\% 5$ level.

\section{Measurement of Total Phenolic (TPC) and Total Flavonoid Content (TFC)}

Total phenolic and flavonoid quantities of G. elwesii samples are presented in Table 2. In the the ultrasonic-assisted extraction method, total phenolic and flavonoid amounts were higher than those of maceration method. The highest total phenolic content in ultrasonic-assisted extraction was determined as $45.58 \mathrm{mg}$ GAE $\mathrm{g}^{-1} \mathrm{DW}$ in the leaf samples harvested during fruit set, followed by $45.13 \mathrm{mg} \mathrm{GAE} \mathrm{g}^{-1} \mathrm{DW}$ in the bulb samples harvested at the same period. These values are lower in the leaf

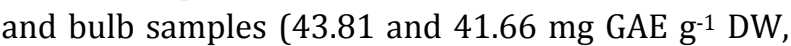
respectively) in the extraction with maceration. The period in which the total phenolic amount in the leaf and bulb samples was highest (45.58 and $45.13 \mathrm{mg}$ GAE $\mathrm{g}^{-1}$ DW) was fruit set, followed by postflowering (33.15 and 36.43 GAE/g DW, respectively) and flowering (28.76 and $31.40 \mathrm{mg}^{\mathrm{GAE}} \mathrm{g}^{-1} \mathrm{DW}$, respectively). In the root samples, the total phenolic amount decreased from 25.62 to $19.78 \mathrm{mg}$ GAE g${ }^{1} \mathrm{DW}$, by approximately $22.9 \%$, through flowering to fruit set.

The highest total flavonoid content was determined as $60.92 \mathrm{mg} \mathrm{QE} \mathrm{g}^{-1} \mathrm{DW}$ in the bulb samples harvested during fruit set using ultrasonic-assisted extraction followed by $46.58 \mathrm{mg} \mathrm{QE} \mathrm{g}^{-1} \mathrm{DW}$ in the leaf samples harvested in the same period. In maceration extraction, this value is $53.08 \mathrm{mg} \mathrm{QE} \mathrm{g}^{-1} \mathrm{DW}$ in bulb and $40.63 \mathrm{mg} \mathrm{QE} \mathrm{g}^{-1} \mathrm{DW}$ in leaf. It was determined that the total amount of flavonoid respectively increased by approximately $28.7 \%$ in leafs and $89.8 \%$ in bulbs from flowering to fruit set period. Although the total amount of flavonoids in the leaf and bulb samples is lower in the extraction with maceration, it was determined that there was an increase by approximately $34.6 \%$ in leafs and $78.1 \%$ in bulbs from flowering period to fruit set. In the 
root samples, the highest total amount of flavonoids (UAE: $25.64 \mathrm{mg} \mathrm{QE} \mathrm{g}^{-1} \mathrm{DW}$, ME: $25.33 \mathrm{mg} \mathrm{QE} \mathrm{g}^{-1} \mathrm{DW}$ ) in both extraction methods was detected during flowering period, followed by post-flowering and fruit set.

Recent studies have shown that the total amount of phenolic and flavonoids in species belonging to the family Amaryllidaceae received various values depending on the growth and development periods of plants (Ay et al., 2018), plant parts (Rokbeni et al., 2016), cultural practicesses, climate and environmental factors (Tkaidza et al., 2018). Karimi et al. (2018) studied on G. transcaucasus and reported that the total phenolic and flavonoid content (4.45 and $2.67 \mathrm{mg} \mathrm{QE} \mathrm{g}^{-1}$ DW respectively) was highest in shoot samples, which were followed by flower samples (3.85 and $2.26 \mathrm{mg} \mathrm{QE} \mathrm{g}^{-1} \mathrm{DW}$, respectively) and bulb samples (3.41 and $1.06 \mathrm{mg} \mathrm{QE}$ $\mathrm{g}^{-1}$ DW). Ay et al. (2018) reported that the total phenolic and flavonoid content of $G$. elwesii were mostly higher in bulb samples harvested during fruit ripening (42.63 and $58.63 \mathrm{mg}$ QE $\mathrm{g}^{-1}$ DW, respectively), which was followed by leaf samples harvested during the same period (42.58 and 43.21 mg QE $\mathrm{g}^{-1}$ DW, respectively). A study of three different Galanthus species (G. woronowii, G. elwesii and G. nivalis) showed that the TPC and TFC was higher in the leaves than in the bulbs (Bulduk and Karafakıoğlu, 2019). In different study, Benedec et al. (2018) reported that the aerial parts of $G$. nivalis were richer higher in the amount of phenolic and flavonoids than other species of Amaryllidaceae $(N$. poeticus, $L$. vernum and $N$. pseudonarcissus). These results show that $G$. elwesii is rich in the total phenolic and flavonoid quantities, compared to $G$. nivalis, G. woronowii, G. transcaucasicus, N. poeticus, L. vernum and $N$. pseudonarcissus and that aerial parts are higher in the total phenolic and flavonoid content. Moreover, the growth development periods have an effect on the change of TPC and TFC, and the UAE method is more effective than the maceration method.

\section{Antioxidant Activity}

Antioxidant activity results of $G$. elwesii samples are presented in Table 3. In UAE method, the DPPH radical scavenging capacity of the samples to ranged from $50.35 \%$ to $80.41 \%$, while in ME these values ranged from $46.27 \%$ to $78.75 \%$. The weakest radical scavenging capacity was obtained as $46.27 \%$ (ME) from the flower samples, while the strongest radical scavenging capacity was obtained as $80.41 \%$ (UAE) from the leaf samples harvested during fruit set period. This was followed by the bulbs harvested in the same period with $79.54 \%$ (UAE) and the leaf specimen harvested in the post-flowering period with $79.51 \%$ (UAE). According to the plant development periods, radical scavenging capacity of leaf and bulb samples from flowering period to fruit set period increased by about $31.7 \%$ in the leaf and $47.4 \%$ in the bulb. Although the radical scavenging capacity of the leaf and bulb samples in maceration extraction is lower compared to the ultrasonic assisted extraction method, an increase of $21.5 \%$ in leaf and $51.6 \%$ in bulb from the flowering period to the fruit set period was found. In the root samples, the highest radical scavenging capacity (UAE: $71.9 \%$, ME: $69.32 \%$ ) in both extraction methods was determined during fruit set, followed by flowering and post-flowering.

According to the reducing power analysis, the antioxidant activity of the samples ranged from 0.138 to 0.387 in the ultrasonic-assisted extraction (UAE) method, while these values ranged from 0.073 to 0.276 in the maceration extraction (ME) method. The highest activity was 0.387 (UAE) in the leaves harvested during the fruit set period, while the lowest activity was 0.073 (ME) in the root samples harvested during the same period. This was followed by the samples of bulbs harvested during the fruit set period with 0.319 (UAE). According to the plant development periods, the activity of the leaf and bulb samples increased by $118.6 \%$ in the leaf and $108.5 \%$ in the bulb from flowering period to fruit set period. Although the activity of the leaf and bulb samples in the extraction with maceration was lower compared to the ultrasonic-assisted extraction method, there was an increase of $95.7 \%$ in the leaf and $85.4 \%$ in the bulb from the flowering to fruit set. In the root samples, the highest activity (UAE: 0.205, ME: 0.167) in both extraction methods was detected during flowering period. The activity of the root samples harvested during post-flowering and fruit set decreased in both extraction methods.

In the UAE method, the chelating ability of the samples ranged from $51.07 \%$ to $81.92 \%$, while these values ranged from $40.39 \%$ to $68.75 \%$ in the $\mathrm{ME}$ method. The highest chelating ability was found as $81.92 \%$ (UAE) in the root samples harvested in postflowering period, while the lowest chelating ability was $40.39 \%$ (ME) in the leaf harvested during fruit set. According to the plant growth periods, the chelating ability of the leaf specimen in both 
extraction methods increases from flowering to fruit set, while this increase in the bulbs continues from flowering to post-flowering period and then it decreased until fruit set period. In the root samples, the highest activity in both extraction methods (UAE: 76.41\%, ME: 68.75\%) was determined during flowering period, followed by fruit set and postflowering.

Table 3. Antioxidant potential of the extracts obtained by the ultrasonic-assisted and maceration methods according to the phenological stages and plant parts.

\begin{tabular}{|c|c|c|c|c|c|c|}
\hline \multicolumn{7}{|c|}{ DPPH free radical scavenging activity assay (\%)* } \\
\hline \multicolumn{7}{|c|}{$\begin{array}{c}\text { Phenological stages } \\
\end{array}$} \\
\hline & \multicolumn{2}{|c|}{ Flowering } & \multicolumn{2}{|c|}{ Post-flowering } & \multicolumn{2}{|c|}{ Fruit set } \\
\hline Plant parts & $\begin{array}{c}\text { Ultrasonic } \\
\text { assisted }\end{array}$ & Maceration & $\begin{array}{c}\text { Ultrasonic } \\
\text { assisted }\end{array}$ & Maceration & $\begin{array}{c}\text { Ultrasonic } \\
\text { assisted }\end{array}$ & Maceration \\
\hline Leaf & $61.05 \pm 0.72^{b}$ & $60.68 \pm 0.60^{b}$ & $79.51 \pm 1.48^{\mathrm{a}}$ & $72.24 \pm 0.83^{a}$ & $80.41 \pm 1.20^{\mathrm{a}}$ & $73.70 \pm 2.17^{b}$ \\
\hline Flower & $50.35 \pm 1.10^{\mathrm{d}}$ & $46.27 \pm 0.30^{\mathrm{d}}$ & & & & \\
\hline Bulb & $53.97 \pm 0.44^{c}$ & $51.96 \pm 0.64^{c}$ & $69.33 \pm 0.77^{b}$ & $63.76 \pm 0.70^{b}$ & $79.54 \pm 1.00^{\mathrm{b}}$ & $78.75 \pm 2.00^{\mathrm{a}}$ \\
\hline Root & $68.25 \pm 0.21^{\mathrm{a}}$ & $63.38 \pm 0.92^{\mathrm{a}}$ & $52.63 \pm 0.18^{c}$ & $49.56 \pm 1.08^{c}$ & $71.90 \pm 0.56^{c}$ & $69.32 \pm 0.33^{c}$ \\
\hline \multicolumn{7}{|l|}{ Standards } \\
\hline BHT & 94.690 & & & & & \\
\hline Trolox & 90.570 & & & & & \\
\hline BHA & 82.470 & & & & & \\
\hline \multicolumn{7}{|c|}{ Reducing power assay* } \\
\hline \multicolumn{7}{|c|}{ Phenological stages } \\
\hline & \multicolumn{2}{|c|}{ Flowering } & \multicolumn{2}{|c|}{ Post-flowering } & \multicolumn{2}{|c|}{ Fruit set } \\
\hline Plant parts & $\begin{array}{c}\text { Ultrasonic } \\
\text { assisted }\end{array}$ & Maceration & $\begin{array}{c}\text { Ultrasonic } \\
\text { assisted }\end{array}$ & Maceration & $\begin{array}{c}\text { Ultrasonic } \\
\text { assisted }\end{array}$ & Maceration \\
\hline Leaf & $0.177 \pm 0.12^{\mathrm{b}}$ & $0.141 \pm 0.11^{\mathrm{b}}$ & $0.212 \pm 0.25^{\mathrm{b}}$ & $0.185 \pm 0.00^{\mathrm{a}}$ & $0.387 \pm 0.41^{\mathrm{a}}$ & $0.276 \pm 0.33^{\mathrm{a}}$ \\
\hline Flower & $0.138 \pm 0.17^{d}$ & $0.096 \pm 0.09 \mathrm{c}$ & & & & \\
\hline Bulb & $0.153 \pm 0.09^{c}$ & $0.103 \pm 0.10^{c}$ & $0.238 \pm 0.08^{\mathrm{a}}$ & $0.154 \pm 0.22^{\mathrm{b}}$ & $0.319 \pm 0.08^{b}$ & $0.191 \pm 0.13^{\mathrm{b}}$ \\
\hline Root & $0.205 \pm 0.03^{a}$ & $0.167 \pm 0.17 \mathrm{a}$ & $0.105 \pm 0.15^{c}$ & $0.078 \pm 0.09 \mathrm{c}$ & $0.106 \pm 0.00^{c}$ & $0.073 \pm 0.05^{c}$ \\
\hline \multicolumn{7}{|l|}{ Standards } \\
\hline BHT & 0.413 & & & & & \\
\hline Trolox & 0.439 & & & & & \\
\hline BHA & 0.598 & & & & & \\
\hline \multicolumn{7}{|c|}{ Metal chelating activity assay $(\%)^{*}$} \\
\hline \multicolumn{7}{|c|}{ Phenological stages } \\
\hline & \multicolumn{2}{|c|}{ Flowering } & \multicolumn{2}{|c|}{ Post-flowering } & \multicolumn{2}{|c|}{ Fruit set } \\
\hline Plant parts & $\begin{array}{c}\text { Ultrasonic } \\
\text { assisted }\end{array}$ & Maceration & $\begin{array}{c}\text { Ultrasonic } \\
\text { assisted }\end{array}$ & Maceration & $\begin{array}{c}\text { Ultrasonic } \\
\text { assisted }\end{array}$ & Maceration \\
\hline Leaf & $75.72 \pm 3.12^{\mathrm{b}}$ & $61.26 \pm 0.78^{\mathrm{d}}$ & $77.80 \pm 1.68^{a}$ & $66.32 \pm 0.92^{b}$ & $81.92 \pm 0.10^{\mathrm{a}}$ & $67.50 \pm 1.76^{a}$ \\
\hline Flower & $63.42 \pm 1.07^{d}$ & $65.31 \pm 1.24^{c}$ & & & & \\
\hline Bulb & $71.66 \pm 0.80^{c}$ & $66.20 \pm 1.18^{b}$ & $78.75 \pm 3.01^{b}$ & $73.20 \pm 2.45^{\mathrm{a}}$ & $57.32 \pm 0.58^{c}$ & $42.56 \pm 0.50^{c}$ \\
\hline Root & $76.41 \pm 0.46^{a}$ & $68.75 \pm 0.94^{a}$ & $51.07 \pm 1.00^{c}$ & $40.29 \pm 0.63^{c}$ & $65.80 \pm 3.52^{b}$ & $61.22 \pm 0.37^{b}$ \\
\hline \multicolumn{7}{|l|}{ Standards } \\
\hline BHT & 97.5 & & & & & \\
\hline Trolox & 95.45 & & & & & \\
\hline BHA & 97.06 & & & & & \\
\hline
\end{tabular}

[a] The result are expressed as means \pm SD $(\mathrm{n}=3)$; [b] *At $200 \mu \mathrm{g} \mathrm{mL}{ }^{-1}$ concentration; [c] Means with the same letters are not significantly different at $\% 5$ level.

Several previous reports on Amaryllidaceae species provide a very comprehensive overview of the antioxidant activity of these species. Our results show that the leaf and bulb samples during fruit ripening have high antioxidant capacity, similar to the study on G. elwesii by Ay et al. (2018). Further, in another study conducted on P. maritimum, Rokbeni et al. (2016) reported that leaf samples were good radical scavengers. Moreover, Karimi et al. (2018) showed that antioxidant capacity of the flower samples in G. transcaucasicus was higher than that of the bulb samples. In our study, antioxidant activity of the flower samples was higher than those of the leaf, bulb and root samples. In a study on Galanthus reginae-olgae subsp. vernalis, Conforti et al. (2010) indicated that bulb samples showed higher antioxidant activity than aerial parts.

\section{Correlation Among Study Variables}

Correlation coefficients among antioxidant activities by the three assays ( DPPH, MCA and RP), TPC, TFC, galantamine, and lycorine are shown in Table 4. In this study, there were positive and significant correlations of DPPH assay antioxidant activity with galantamine $\left(r=0.351^{*}\right)$ and lycorine $\left(r=0.608^{* *}\right)$, 
with significant correlations of lycorine with MCA ( $\mathrm{r}$ $\left.=0.608^{* *}\right)$ and $\mathrm{RP}\left(\mathrm{r}=0.775^{* *}\right)$ assays. No positive or negative correlation was observed between galantamine and lycorine in correlation analysis.

TPC and three antioxidant activity tests (DPPH, MCA and RP) were positively and significantly correlated at $\mathrm{p}<0.01$ ( $\mathrm{r}=0.828^{* *}, 0.839^{* *}$ and $0.820^{* *}$, respectively). Similarly, TFC showed significant positive correlations with the three antioxidant activity tests (DPPH, MCA and RP) at $\mathrm{p}<0.01$ ( $\mathrm{r}=$
$0.868^{* *}, 0.771^{* *}$ and $908^{* *}$, respectively). In addition, the correlations between DPPH and MCA ( $\mathrm{r}$ $\left.=0.927^{* *}\right)$, DPPH and RP ( $\left.\mathrm{r}=0.837^{* *}\right)$, and MCA and $\mathrm{RP}\left(\mathrm{r}=0.754^{* *}\right)$ was positive and significant. Studies on Amaryllidaceae species have shown a significant and positive correlation of TPC with TFC and antioxidant activity (Assefa et al., 2018; Ay et al., 2018; Ghane et al., 2018). Our results confirmed the relationship of total phenolic with flavonoid content and antioxidant activity.

Table 4. Pearson's correlation coefficients ( $\mathrm{r}$ ) among bioactive compounds and antioxidant capacity of Galanthus elwesii

\begin{tabular}{|c|c|c|c|c|c|c|c|}
\hline Traits & DPPH & MCA & $\mathrm{RP}$ & TPC & TFC & Galantamin & Lycorine \\
\hline DPPH & 1 & & & & & & \\
\hline MCA & $.927^{* *}$ & 1 & & & & & \\
\hline $\mathrm{RP}$ & $.837 * *$ & $.754^{* *}$ & 1 & & & & \\
\hline TPC & $.828^{* *}$ & $.839 * *$ & $.820^{* *}$ & 1 & & & \\
\hline TFC & $.868^{* *}$ & $.771^{* *}$ & $.908^{* *}$ & $.819^{* *}$ & 1 & & \\
\hline Galantamin & $.351^{*}$ & .250 & .005 & .083 & .047 & 1 & \\
\hline Lycorine & $.608^{* *}$ & $.521^{* *}$ & $.775^{* *}$ & $.679 * *$ & $.648^{* *}$ & 0.45 & 1 \\
\hline
\end{tabular}

[a] DPPH: 2,2-diphenyl-1-picrylhydrazyl; [b] MCA: Metal chelating activity; [c] RP: Reducing power; [d] TPC: Total phenolic content; [e] TFC: Total flavonoid content; [f] ${ }^{* *}$ and ${ }^{*}$ Correlation is significant at $\mathrm{p}<0.05$ and $\mathrm{p}<0.01$ probability levels ( 2 tailed), respectively.

\section{Conclusion}

In this study, we extracted several plant parts of G.elwesii at different growth stages using ultrasonicassisted and maceration extraction methods. The results revealed that ultrasonic-assisted extraction was more efficient than maceration extraction for galantamine, lycorine, total phenolic, and flavonoid content. Ultrasonic-assisted extraction method was found to be more effective than the maceration extraction in terms of the three assays (DPPH, MCA, and RP) used to determine antioxidant activity. Similarly, galantamine, lycorine, total phenolic, flavonoid amounts and antioxidant activity were more effective in ultrasonic assisted extraction method regardless of plant growth periods and plant parts. The results revealed that the ultrasoundassisted extraction method is more effective than the maceration method. Maybe this method can be effective in other species.

\section{References}

Assefa, A.D., Jeong, Y.J., Kim, D.J., Jeon, Y. A., Lee, J. R., Ko, H.C., Baek, H.J., \& Sung, J.S. (2018). Assessing phenolic content and antioxidant potential diversity in Allium plants using multivariate data analysis. Horticulture, Environment, and Biotechnology, 59, 759-773.
Ay, E.B., Gül, M., Açıkgöz, M.A., Yarilgaç, T., \& Kara, Ş.M. (2018). Assessment of antioxidant activity of giant snowdrop (Galanthus elwesii Hook) extracts with their total phenol and flavonoid contents. Indian Journal of Pharmaceutical Education and Research, 52, 128-132.

Azmir, J., Zaidul, I.S.M., Rahman, M.M., Sharif, K.M., Mohamed, A., Sahena, F., Jahurul, M. H. A., Ghafoor, N.A.N., \& Omar, A.K.M. (2013). Techniques for extraction of bioactive compounds from plant materials: A review. Journal of Food Engineering, $117,426-436$.

Benedec, D., Oniga, I., Hanganu, D., Gheldiu, A. M., Pușcaș, C., Silaghi-Dumitrescu, R., Duma, M., Tiperciuc, B., Vârban, R., \& Vlase, L. (2018). Sources for developing new medicinal products: biochemical investigations on alcoholic extracts obtained from aerial parts of some Romanian Amaryllidaceae species. BMC Complementary Medicine and Therapies, 18, 226.

Brand-Williams, W., Cuvelier, M.E. \& Berset, C.L.W.T. (1995). Use of a free radical method to evaluate antioxidant activity. LWT- Food Science and Technology, 28, 25-30.

Bulduk, I., \& Karafakıoğlu, Y.S. (2019). Evaluation of galantamine, phenolics, flavonoids and antioxidant content of Galanthus species in Turkey. International Journal of Biochemistry Research \& Review, 1-12. 
Chemat, F., \& Khan, M.K. (2011). Applications of ultrasound in food technology: processing, preservation and extraction. Ultrasonics Sonochemistry, 18, 813-835.

Chemat, F., Rombaut, N., Sicaire, A.G., Meullemiestre, A., Fabiano-Tixier, A.S., \& Abert-Vian, M. (2017). Ultrasound assisted extraction of food and natural products. Mechanisms, techniques, combinations, protocols and applications. Ultrasonics Sonochemistry, 34, 540-560.

Christenhusz, M. J. \& Byng J. W. (2016). The number of known plants species in the world and its annual increase. Phytotaxa, 261, 201-217.

Cimmino, A., Masi, M., Evidente, M., Superchi, S., \& Evidente, A. (2017). Amaryllidaceae alkaloids: Absolute configuration and biological activity. Chirality, 29, 486-499.

Conforti, F., Loizzo, M.R., Marrelli, M., Menichini, F., Statti, G.A., Uzunov, D., \& Menichini, F. (2010). Quantitative determination of Amaryllidaceae alkaloids from Galanthus reginae-olgae subsp. vernalis and in vitro activities relevant for neurodegenerative diseases. Pharmaceutical Biology, 48, 2-9.

Cortes, N., Sabogal-Guaqueta, A. M., Cardona-Gomez, G. P., \& Osorio, E. (2019). Neuroprotection and improvement of the histopathological and behavioral impairments in a murine Alzheimer's model treated with Zephyranthes carinata alkaloids. Biomedicine \& Pharmacotherapy, 110, 482-492.

Costa, G.G.P., Silva, C.A.G., Gomes, J.V.D., Torres, A.G., Santos, I.R.I., de Almeida, F.T.C., Fagg, C.W., Simeoni, L. A., Silveira, D., \& Gomes-Copeland, K. K. P. (2019). Influence of in vitro micropropagation on lycorine biosynthesis and anticholinesterase activity in Hippeastrum goianum. Revista Brasileira de Farmacognosia, 29, 262-265.

Decker, E. A., \& Welch, B. (1990). Role of ferritin as a lipid oxidation catalyst in muscle food. Journal of Agricultural and Food Chemistry, 38, 674-677.

Emir, A., Emir, C., Bozkurt, B., Onur, M.A., Somer, N.U., \& Kaya, G.I. (2017). Application of HPLC-DAD for the quantification of Lycorine in Galanthus elwesii Hook. Brazilian Journal of Pharmaceutical Sciences, 53.

Emir, A., \& Önür, M. A. (2016). Simultaneous Quantification of Galanthamine and Lycorine in Galanthus fosteri by HPLC-DAD. Marmara Pharmaceutical Journal, 20.

Fazal, H., Abbasi, B.H., Ahmad, N., Ali, S.S., Akbar, F., \& Kanwal, F. (2016). Correlation of different spectral lights with biomass accumulation and production of antioxidant secondary metabolites in callus cultures of medicinally important Prunella vulgaris L. Journal of Photochemistry and Photobiology B: Biology, 159, 1-7.

Ghane, S. G., Attar, U. A., Yadav, P.B., \& Lekhak, M.M. (2018). Antioxidant, anti-diabetic, acetylcholinesterase inhibitory potential and estimation of alkaloids (lycorine and galanthamine) from Crinum species: An important source of anticancer and antiAlzheimer drug. Industrial Crops and Products, 125, 168-177.

He, M., Qu, C., Gao, O., Hu, X., \& Hong, X. (2015). Biological and pharmacological activities of amaryllidaceae alkaloids. RSC Advances, 5, 16562-16574.

Houghton, P.J., Ren, Y. \& Howes, M.J. (2006). Acetylcholinesterase inhibitors from plants and fungi. Natural Product Reports, 23, 181-199.

Karimi, E., Mehrabanjoubani, P., Homayouni-Tabrizi, M., Abdolzadeh, A., \& Soltani, M. (2018). Phytochemical evaluation, antioxidant properties and antibacterial activity of Iranian medicinal herb Galanthus transcaucasicus Fomin. Journal of Food Measurement and Characterization, 12, 433-440.

Khonakdari, M.R., Mirjalili, M. H., Gholipour, A., Rezadoost, H., \& Farimani, M.M. (2018). Quantification of galantamine in Narcissus tazetta and Galanthus nivalis (Amaryllidaceae) populations growing wild in Iran. Journal of Plant Genetic Resources, 16, 188192.

Nair, J.J., Bastida, J., Codina, C., Viladomat, F., \& Van Staden J. (2013). Alkaloids of the South African Amaryllidaceae: a review. Natural Product Communications, 8.

Nair, J.J., \& Van Staden, J. (2013). Pharmacological and toxicological insights to the South African Amaryllidaceae. Food and Chemical Toxicology, 62, 262-275.

Nair, J.J., \& Van Staden, J. (2014). Traditional usage, phytochemistry and pharmacology of the South African medicinal plant Boophone disticha (Lf) Herb. (Amaryllidaceae). Journal of Ethnopharmacology, 151, 12-26.

Oyaizu, M. (1986). Studies on products of browning reaction. The Japanese Journal of Nutrition and Dietetics, 44, 307-315.

Van Goietsenoven, G., Mathieu, V., Lefranc, F., Kornienko, A., Evidente, A., \& Kiss, R. (2013). Narciclasine as well as other Amaryllidaceae isocarbostyrils are promising GTP-ase targeting agents against brain cancers. Medicinal Research Reviews, 33, 439-455. 
Petruczynik, A., Misiurek, J., Tuzimski, T., Uszyński, R., Szymczak, G., Chernetskyy, M., \& Waksmundzka, Hajnos, M. (2016). Comparison of different HPLC systems for analysis of galantamine and lycorine in various species of Amaryllidaceae family. Journal of Liquid Chromatography \& Related Technologies, 39, 574-579.

Rokbeni, N., M'rabet, Y., Cluzet, S., Richard, T., Krisa, S., Boussaid, M., \& Boulila, A. (2016). Determination of phenolic composition and antioxidant activities of Pancratium maritimum L. from Tunisia. Industrial Crops and Products, 94, 505-513.

Seal, T. (2016). Quantitative HPLC analysis of phenolic acids, flavonoids and ascorbic acid in four different solvent extracts of two wild edible leaves, Sonchus arvensis and Oenanthe linearis of North-Eastern region in India. Journal of Applied Pharmaceutical Science, 6(2), 157-166.

Takaidza, S., Mtunzi, F., \& Pillay, M. (2018). Analysis of the phytochemical contents and antioxidant activities of crude extracts from Tulbaghia species. Journal of Liquid Chromatography \& Related Technologies, 38, 272-279.

Tarakemeh, A., Azizi, M., Rowshan, V., Salehi, H., Spina, R., Dupire, F., Arouie, H., \& Laurain-Mattar, D. (2019). Screening of Amaryllidaceae alkaloids in bulbs and tissue cultures of Narcissus papyraceus and four varieties of $N$. tazetta. Journal of Pharmaceutical and Biomedical Analysis, 172, 230-237.

Van Goietsenoven, G., Mathieu, V., Lefranc, F., Kornienko, A., Evidente, A., \& Kiss, R. (2013). Narciclasine as well as other Amaryllidaceae isocarbostyrils are promising GTP-ase targeting agents against brain cancers. Medicinal Research Reviews, 33, 439-455.

Vinatoru, M. (2001). An overview of the ultrasonically assisted extraction of bioactive principles from herbs. Ultrasonics Sonochemistry, 8, 303-313.

Vongsak, B., Gritsanapan, W., Wongkrajang, Y., \& Jantan, I. (2013). In vitro inhibitory effects of Moringa oleifera leaf extract and its major components on chemiluminescence and chemotactic activity of phagocytes. Natural Product Communications, 8.

Wang, W., Li, Q., Liu, Y. \& Chen, B. (2015). Ionic liquidaqueous solution ultrasonic-assisted extraction of three kinds of alkaloids from Phellodendron amurense Rupr and optimize conditions use response surface. Ultrasonics Sonochemistry, 24, 1318.

Wolfe, K., Wu, X., \& Liu, R. H. (2003). Antioxidant activity of apple peels. Journal of Agricultural and Food Chemistry, 51, 609-614.

Yang, L., Wang, H., Zu, Y. G., Zhao, C., Zhang, L., Chen, X., \& Zhang, Z. (2011). Ultrasound-assisted extraction of the three terpenoid indole alkaloids vindoline, catharanthine and vinblastine from Catharanthus roseus using ionic liquid aqueous solutions. Chemical Engineering Journal, 172, 705-712.

Zhang, L., Geng, Y., Duan, W., Wang, D., Fu, M., \& Wang, X. (2009). Ionic liquid-based ultrasound-assisted extraction of fangchinoline and tetrandrine from Stephaniae tetrandrae. Journal of Separation Science, 32, 3550-3554. 